\title{
Ocena wybranych opracowań ekofizjograficznych z obszarów wiejskich południowo-wschodniej Polski
}

\section{Assessment of the selected eco-physiographic studies of rural areas of south-eastern Poland}

\section{Bogusława BARAN-ZGŁOBICKA}

Uniwersytet Marii Curie-Skłodowskiej w Lublinie

Wydział Nauk o Ziemi i Gospodarki Przestrzennej, Zakład Polityki Przestrzennej i Planowania

al. Kraśnicka 2CD, 20-718 Lublin

bbaran@umcs.pl

Zarys treści: Opracowanie ekofizjograficzne jest podstawowym dokumentem charakteryzującym uwarunkowania przyrodnicze na potrzeby planowania przestrzennego. Na podstawie pełnego rozpoznania środowiska przyrodniczego wskazuje się w nim obszary predysponowane do pełnienia określonych funkcji społeczno-gospodarczych i ekologicznych. Obowiązkowo powinno być przygotowane do projektów planu zagospodarowania przestrzennego województwa, studium uwarunkowań i kierunków zagospodarowania przestrzennego gminy oraz do miejscowych planów zagospodarowania przestrzennego. Celem pracy jest ocena opracowań ekofizjograficznych sporządzonych dla dziewięciu gmin wiejskich południowo-wschodniej Polski. Badania szczegółowe obejmowały analizę zawartości i jakości merytorycznej informacji przyrodniczej oraz poprawności ujęcia i formułowania ocen, prognoz i wskazań w tych dokumentach. Pod względem formalnym ekofizjografie te są kompletne i opracowane zgodnie z wymogami prawnymi. Zawierają pełną charakterystykę komponentów środowiska przyrodniczego. Stwierdzono jednak elementy, które wymagają korekt i uzupełnień. Występują braki w zakresie identyfikacji: a) problemów zagospodarowania i użytkowania środowiska, b) oceny odporności środowiska na degradację, c) barier dla zagospodarowania, d) rzeczywistych i potencjalnych konfliktów.

Słowa kluczowe: zasoby przyrodnicze, obszary wiejskie, opracowanie ekofizjograficzne.

\section{Wstęp}

W rozwoju gospodarczym obszarów zurbanizowanych i wiejskich ogromne znaczenie mają zasoby przyrodnicze: ich rodzaj, wielkość i jakość. Nazywa się je także zasobami naturalnymi albo zasobami środowiska. Dzielone są na odnawialne i nieodnawialne (wyczerpywalne i niewyczerpywalne) lub trudno odnawialne. Można mówić o zasobach geosfery: atmosfery, hydrosfery, litosfery, pedosfery i biosfery (Kistowski 2009). Znajdują się one w określonej przestrzeni geograficznej, w której zachodzą również procesy przyrodnicze i społeczno-gospodarcze, powodujące przekształcenia zarówno zasobów, jak i przestrzeni. Nie można zapominać o tym, że sama przestrzeń jednocześnie też jest 
zasobem środowiska przyrodniczego. Właściwe gospodarowanie przestrzenią z zachowaniem ładu przestrzennego i zrównoważonego rozwoju zgodnie z art. 1 ust. 1 Ustawy o planowaniu i zagospodarowaniu przestrzennym (tekst jednolity Dz.U. 2016 poz. 778) stanowi jedno z trudniejszych zadań planowania przestrzennego. Działania planistyczne powinny uwzględniać racjonalne gospodarowanie środowiskiem i jego zasobami. Dlatego tak ważne jest pełne rozpoznanie zasobów przyrodniczych przed przystąpieniem do procesu planistycznego.

B. Poskrobko (2007, s. 10) określa pojęcie gospodarowania środowiskiem jako „korzystanie z zasobów i walorów przyrody dla zaspokojenia potrzeb osobniczych i społecznych ludzi (...) ". Natomiast termin gospodarowanie zasobami środowiska zostaje użyty w ustawie Prawo ochrony środowiska (tekst jednolity Dz. U. 2016 poz. 672) przy definiowaniu ochrony środowiska, która m.in. ma polegać na „racjonalnym kształtowaniu środowiska i gospodarowaniu zasobami środowiska zgodnie z zasadą zrównoważonego rozwoju" (art. 3 pkt 13). W tym kontekście należy uznać, że gospodarowanie zasobami środowiska wiąże się z procesami jego racjonalnego kształtowania (Rakoczy 2014). Powinno też uwzględniać różnorodne czynniki i ich wzajemne powiązania, czyli mieć charakter systemowy, a podstawą wszelkich działań musi być planowanie (Bar i in. 2011).

Odniesienia do zasobów środowiska można doszukiwać się w ustawie Prawo ochrony środowiska (tekst jednolity Dz. U. 2016 poz. 672) w definicji legalnej samego środowiska, rozumianego jako: „ogół elementów przyrodniczych, w tym także przekształconych w wyniku działalności człowieka, a w szczególności powierzchnię ziemi, kopaliny, wody, powietrze, krajobraz, klimat oraz pozostałe elementy różnorodności biologicznej, a także wzajemne oddziaływania pomiędzy tymi elementami" (art. 3 pkt 39). W tych elementach należy dostrzegać zasoby przyrodnicze.

Zasoby przyrodnicze o wysokich walorach podlegają ochronie, która wg ustawy o ochronie przyrody (tekst jednolity Dz. U. 2015, poz. 1651, art. 2.1) „polega na zachowaniu, zrównoważonym użytkowaniu oraz odnawianiu zasobów, tworów i składników przyrody (...) ". Ustawa ta reguluje gospodarowanie zasobami i składnikami przyrody. Natomiast zakres gospodarowania i ochrony poszczególnych zasobów środowiska określają przepisy szczególne, które dotyczą m.in. wód, surowców mineralnych, lasów, gruntów rolnych i leśnych itp. (Nowak 2013; Fogel 2014).

Ustawa o zachowaniu narodowego charakteru strategicznych zasobów naturalnych kraju (Dz. U. 2001/97, poz. 1057 z późn. zm.) wprowadza specjalną kategorię strategicznych naturalnych zasobów kraju, do których należą zasoby wodne, wody polskich obszarów morskich, lasy państwowe, złoża kopalin (nieobjęte prawem własności nieruchomości gruntowej) oraz zasoby przyrodnicze parków narodowych. W tym przypadku kategoria zasobów przypisywana jest tym składnikom środowiska, które są wykorzystywane gospodarczo, ale w ściśle określonym zakresie (Haładyj i Trzewik 2014).

Wartość zasobów przyrodniczych jest wypadkową wielu czynników. Wyznaczają ją takie cechy, jak: rzadkość i ograniczoność występowania, zróżnicowanie rozmieszczenia, stopień przekształcenia i jakość. Mają one charakter naturalny, ale działalność człowieka może je przekształcać i modyfikować, obniżając lub podnosząc ich wartość. Działania gospodarcze powinny uwzględniać potrzebę ograniczenia strat przy eksploatacji zasobów nieodnawialnych, a przy odnawialnych zrównoważonego ich użytkowania. Gospodarowanie zasobami odbywa się w wydzielanej przestrzeni ekonomicznej, przeznaczonej do realizacji określonych funkcji (Poskrobko 2007; Karpa i in. 2010). 
Z punktu widzenia prawidłowego gospodarowania i ochrony zasobów przyrodniczych ogromne znaczenie ma poziom rozwoju obszarów wiejskich, który coraz częściej przyjmuje kierunek wielofunkcyjny (Feltynowski 2009; Heffner 2015), także w zakresie różnicowania profilu samego rolnictwa (Wilkin 2010). Jednocześnie pojawiają się niekontrolowane zjawiska oraz problemy przestrzenne i rozwojowe, np. suburbanizacja w strefach podmiejskich (Czarnecki 2009) czy niekorzystne procesy społeczno-gospodarcze w obszarach peryferyjnych (Bański i in. 2014; Rosner i Stanny 2014). W jakim zakresie polska wieś wykorzysta swój kapitał lokalny w rozwoju, uwarunkowane jest wieloma czynnikami, ale podstawową determinantę stanowi środowisko przyrodnicze i jego zasoby (Bański 2013).

Planowanie przestrzenne może być ważnym instrumentem prawidłowego kształtowania środowiska przyrodniczego, poprawy jego stanu i ochrony zasobów, ale jest przede wszystkim instrumentem ukierunkowania rozwoju przestrzennego i w znacznym stopniu społeczno-gospodarczego. Jedynie kompleksowe i systemowe ujęcie zasobów przyrodniczych w planowaniu pozwala podejmować słuszne decyzje, zarówno w kontekście ochrony środowiska, jak i lokalizacji zjawisk gospodarczych. Dobre rozpoznanie uwarunkowań środowiskowych, w tym zasobów przyrodniczych to nie tylko ich diagnoza, ale również ocena, na ile predysponują do kreowania określonego kierunku rozwoju gospodarczego i czy obiektywnie są podstawą wskazań właściwej funkcji w planowaniu przestrzennym (Kozłowski 1996; Dubel 2000; Bródka 2010; Macias i Bródka 2014). Ze względu na samodzielność planistyczną gmin szczególnie istotna jest w tym przypadku polityka gospodarcza i przestrzenna szczebla lokalnego.

Do analiz wybrano opracowania ekofizjograficzne, jako podstawowe źródło informacji przyrodniczej specjalnie zebranej i przygotowanej dla procesu planistycznego. Celem pracy jest próba oceny ekofizjografii sporządzonych dla dziewięciu gmin wiejskich południowo-wschodniej Polski, regionu o bardzo zróżnicowanych zasobach środowiska i wysokich walorach przyrodniczych. Badania szczegółowe obejmowały analizę zawartości i jakości merytorycznej informacji przyrodniczej oraz poprawności ujęcia i formułowania ocen, prognoz i wskazań w tych dokumentach.

\section{Opracowanie ekofizjograficzne}

Dokumenty określające uwarunkowania fizjograficzne pod różne funkcje użytkowe mają długą historię (Różycka 1986; Stala 2001). Obowiązek sporządzenia opracowania ekofizjograficznego wynika z ustawy Prawo ochrony środowiska (tekst jednolity Dz. U. 2016 poz. 672). Art. 72 ust. 5 tej ustawy definiuje je jako dokumentację wykonywaną „na potrzeby studium uwarunkowań i kierunków zagospodarowania przestrzennego gminy, miejscowego planu zagospodarowania przestrzennego oraz planu zagospodarowania przestrzennego województwa, charakteryzującą poszczególne elementy przyrodnicze na obszarze objętym studium lub planem i ich wzajemne powiązania". Jego podstawowym celem jest spełnienie wymagań wymienionych w art. 72 ust. 1-3, które dotyczą szczegółowych ustaleń w zakresie realizacji potrzeb ochrony środowiska i zrównoważonego rozwoju, jakie powinny znaleźć się w treści wyżej wymienionych dokumentów (Bar 2011; Gruszecki 2011).

Mimo braku formalnego włączenia do systemu planowania, bo nie mieści się w procedurach określonych Ustawq o planowaniu i zagospodarowaniu przestrzennym (art. 3, tekst jednolity Dz. U. 2016 poz. 778), opracowanie ekofizjograficzne stanowi ważne 
ogniwo procesu planistycznego. Jest podstawowym źródłem nie tylko samej informacji o zasobach przyrodniczych uzyskanej na podstawie pełnego rozpoznania środowiska przyrodniczego, ale przedstawia jego możliwe wykorzystanie i zakres ochrony oraz ograniczenia źródeł zagrożeń. Określa uwarunkowania przyrodnicze dla różnych form zagospodarowania i użytkowania, czyli wskazuje obszary predysponowane do pełnienia określonych funkcji społeczno-gospodarczych i ekologicznych (Stala 2001; Kistowski 2001a, b, 2002; Kowalczyk 2001; Papińska 2007; Cichocki 2006, Kistowski i Pchałek 2009). Jego treść i rodzaj reguluje Rozporzqdzenie Ministra Środowiska w sprawie opracowań ekofizjograficznych (2002). Dokument powinien zawierać aktualne informacje o środowisku (§ 1 pkt 1). Ta ocena aktualności ekofizjografii jest bardzo ważna przed przystąpieniem do sporządzania aktów planistycznych. Jeśli mogły zaistnieć zmiany w środowisku istotne w kontekście działań planistycznych, to wykorzystanie jej wskazań w tym zakresie może być nawet przesłanką formalną dającą podstawę stwierdzenia nieważności aktu planistycznego (Derucka 2010, 2013; Gruszecki 2011; Szlachetko 2014).

Problematyczny jest zakres treści ekofizjografii sporządzanych do różnych dokumentów planistycznych. Mimo nowelizacji ustawy Prawo ochrony środowiska z 2004 r. (Dz. U. 49/2004 poz. 464), w której dopisano obowiązek wykonania opracowania również do studium, nie ma odrębnego aktu wykonawczego określającego jego zawartość, a wcześniejsze Rozporzq̨dzenie (2002) wymienia jedynie plany. I. Derucka (2013) uważa, że przepisy rozporządzenia należy stosować także w opracowaniach sporządzanych na potrzeby studium. Natomiast zespół autorski przygotowujący opracowanie ekofizjograficzne dla miasta Kielce (Szulczewska i in. 2009) stoi na stanowisku, że w tym przypadku ten akt wykonawczy nie obowiązuje.

Zgodnie z § 1 Rozporzq̨dzenia w opracowaniu ekofizjograficznym należy przedstawić kompleksową charakterystykę środowiska, biorąc pod uwagę dostosowanie zagospodarowania przestrzennego do uwarunkowań środowiskowych, zapewnienie trwałości procesów przyrodniczych i odnawialności zasobów, konieczność ograniczenia zagrożeń i negatywnych zjawisk oraz wskazanie obszarów zdegradowanych do rekultywacji. Wyróżniono dwa rodzaje opracowań (§ 2): podstawowe - wykonywane dla większości projektów planów miejscowych i planów zagospodarowania przestrzennego województw oraz problemowe - przygotowywane dla obszarów wymagających dokładniejszego rozpoznania pewnych cech środowiska przyrodniczego (np. szczególnie wartościowych) lub zagrożonych. Przy czym to pierwsze opracowuje się przed przystąpieniem do prac nad projektem, natomiast drugie przed bądź w trakcie ( $\$ 3$ Rozporzqdzenia).

Proces przygotowania opracowania ekofizjograficznego obejmuje kompleksowe badania i pomiary terenowe oraz zebranie różnorodnych materiałów archiwalnych (§ 4), które mogą wymagać aktualizacji. Źródła kartograficznej informacji przyrodniczej wykorzystywane w ekofizjografii (Kistowski 2001a, 2003) są bardzo zróżnicowane w zależności od rodzaju dokumentu, do którego jest wykonywana i obszaru, którego dotyczy. W ostatnich latach sytuacja bardzo się poprawiła. Mamy zdecydowanie większy zasób przestrzennej informacji przyrodniczej w wersji cyfrowej (Kistowski 2014).

Ekofizjografia składa się z części kartograficznej i opisowej (§ 5). W części graficznej opracowania podstawowego powinny znaleźć się mapy analityczne przedstawiające przestrzenną zmienność poszczególnych elementów środowiska oraz mapy syntetyczne kompleksowych ocen i waloryzacji. Zakres tematyczny części kartograficznej i opisowej ekofizjografii jest bardzo szeroki. M. Kistowski (2001b) wydziela w nim 4 zasadnicze etapy: 
diagnozy, oceny, prognozy i wskazań. Przy małym zasobie materiałów archiwalnych i konieczności szczegółowych badań terenowych już sama diagnoza może być czasochłonna i kosztowna. Trudnym zagadnieniem jest przede wszystkim charakterystyka funkcjonowania środowiska (§ 6 pkt 1), do której zazwyczaj brakuje danych ilościowych i analizy muszą być przeprowadzane na podstawie rozpoznania struktury środowiska i skutków procesów przyrodniczych. Prawne formy ochrony zasobów przyrodniczych (także krajobrazu) powinny obejmować wszystkie obszary i formy chronione oraz te planowane, w tym te wynikające z przepisów szczególnych, często pomijane. Istotnym elementem jest przedstawienie zmian związanych z działalnością człowieka: sposobu użytkowania terenu, źródeł antropopresji i jej skutków w środowisku.

Kolejny etap stanowią wielokierunkowe oceny ( $\$ 6$ pkt 2), które mają dać podstawę ustalenia przydatności terenu do realizacji określonych funkcji społeczno-gospodarczych. Ważnym elementem jest ocena zgodności aktualnego użytkowania z uwarunkowaniami przyrodniczymi, będąca wyznacznikiem prawidłowości planowania przyszłych struktur przestrzennych. Jednym z etapów tej części opracowania jest ocena zasięgu barier fizjograficznych i prawnych. Należy przeprowadzić także analizę dotychczasowego zakresu ochrony zasobów i walorów przyrodniczych. Opis może zawierać również ocenę wystąpienia rzeczywistych i potencjalnych konfliktów środowiskowych przy różnych sposobach zagospodarowania terenu (Kistowski 2001b).

Prognoza ( $\$ 6$ pkt 3) powinna przedstawiać skutki zmian w środowisku przy założeniu kontynuacji istniejących form użytkowania i zagospodarowania. Należy wziąć pod uwagę przewidywane zmiany w komponentach środowiska. W ostatniej fazie opracowania ( $\$ 6$ pkt 4-6) następuje bezpośrednie określenie uwarunkowań przyrodniczych, czyli wskazanie potencjalnych obszarów do realizacji poszczególnych funkcji przyrodniczych i społeczno-gospodarczych oraz przedstawienie możliwości minimalizacji skutków antropopresji i polepszenia stanu środowiska. Jest to etap syntezujący wyniki oceny i prognozy, który zawiera bezpośrednie wytyczne dla zespołu przygotowującego projekt dokumentu planistycznego (Kistowski 2002).

Z. Cichocki (2006) identyfikuje najważniejsze obszary problemowe w opracowaniach ekofizjograficznych sporządzanych do projektów planów miejscowych. Porusza on zagadnienia metodyczne dotyczące ocen zgodności dotychczasowego użytkowania i zagospodarowania z uwarunkowaniami środowiskowymi, ocen kierunków i intensywności zmian w środowisku oraz zakresu prognozy. Wspomniany autor zwraca uwagę na specyfikę problematyki opracowań wykonanych do projektów planów miejscowych terenów górniczych. Zupełnie inna będzie także szczegółowość zagadnień poruszanych w przypadku terenów zainwestowanych oraz otwartych z ekspansją osadnictwa i cennych przyrodniczo, zwłaszcza na etapach ocen i wniosków. Natomiast treści zawarte we wstępnej prognozie zmian powinny być ważnym źródłem informacji dla prognozy oddziaływania na środowisko, sporządzanej w ramach strategicznej oceny. Dla zrównoważonego rozwoju jednym z ważniejszych wniosków jest stwierdzenie: „w kwalifikacji poszczególnych terenów pod określone funkcje, w pierwszej kolejności należy wyodrębnić (...) szczególnie cenne przyrodniczo tereny" (Cichocki 2006, s. 39). 


\section{Obszar i metody badań}

Południowo-wschodnia Polska posiada różnorodne zasoby i wysokie walory środowiska przyrodniczego. Badaniami objęto dziewięć gmin wiejskich położonych w województwach: lubelskim - Potok Górny, Susiec, Wąwolnica, podkarpackim - Jarocin, Zaklików, Zarszyn i świętokrzyskim - Fałków, Krasocin, Solec-Zdrój. Większość jednostek ma typowe problemy społeczno-gospodarcze, charakterystyczne dla obszarów wiejskich. Lokalne władze samorządowe poszukują nowych kierunków rozwoju.

Do analiz szczegółowych wybrano jednostki o zróżnicowanej powierzchni i gęstości zaludnienia (tab. 1). Mimo swojej administracyjnej przynależności nie wszystkie są typowymi gminami wiejskimi. Gmina Solec-Zdrój posiada status uzdrowiska, a Wąwolnica i Zaklików (od 2014 r. miejsko-wiejska) mają potencjalne walory uzdrowiskowe. Struktura użytkowania terenu w badanych jednostkach jest zróżnicowana, ale nie wykazuje istotnej zmienności w ostatnim dziesięcioleciu. W gminach: Potok Górny, Wąwolnica, Zarszyn i Solec-Zdrój użytki rolne zajmują ponad 50\% powierzchni. Łąki i pastwiska trwałe stanowią zwykle kilka, kilkanaście procent powierzchni (wyjątek Zarszyn - ponad 36\%). Średnia wielkość gospodarstwa waha się w granicach 5-6 ha (największa 8,2 ha - Potok Górny), co generalnie nie odbiega od przeciętnej w regionie (woj. lubelskie 8,5 ha, woj. podkarpackie 5,1 ha, woj. świętokrzyskie 6,3 ha). Część jednostek ma duży udział lasów (lesistość ponad 50\% w gminach Susiec i Zaklików) i jest to cecha wyróżniająca w stosunku do innych (woj. lubelskie: 23,1\%, woj. podkarpackie: 37,9\%, woj. świętokrzyskie: 28,1\%). Około 20\% powierzchni, przede wszystkim lasów, w gminie Zaklików obejmował poligon wojskowy. Lasy o wysokich walorach stanowią istotny potencjał turystyczny. Bardzo zróżnicowany jest także udział obszarów chronionych. Po tym względem wyróżnia się gmina Solec-Zdrój (ponad 97\%), ale reżim ochronny tych form jest niski (przewaga obszarów chronionego krajobrazu), stąd realnie występują małe ograniczenia dla planowania przestrzennego. Zdecydowanie większe wymagania w tym zakresie muszą być uwzględnione w gminach Susiec i Wąwolnica, w których prawie połowa obszaru leży w obrębie parku krajobrazowego. Nie wszystkie gminy mają w swoich granicach obszary Natura 2000 (Potok Górny, Wąwolnica). Najwyższy udział tej formy ochrony występuje w gminach Susiec i Zaklików. Miejsca noclegowe w obiektach turystycznych oferują gminy posiadające przede wszystkim zasoby uzdrowiskowe i/lub atrakcje przyrodnicze: Solec-Zdrój oraz Susiec i Krasocin, gdzie rozwijają się różne formy turystyki. Dodatkowym miernikiem atrakcyjności turystycznej, będącym także wymiernym wskaźnikiem wyposażenia w infrastrukturę turystyczną, są ścieżki rowerowe. Największą ich długość posiada gmina Susiec.

Poziom wyposażenia w infrastrukturę techniczną (tab. 1) analizowanych jednostek jest bardzo zróżnicowany. W przypadku sieci wodociągowej udział osób korzystających zwykle przekracza 75\%. Jedynie w gminie Zarszyn wynosi 40,1\%. Z punktu widzenia ochrony środowiska bardzo niekorzystny jest mały udział mieszkańców korzystających z sieci kanalizacyjnej. Problem ten występuje w gminach woj. lubelskiego (Susiec, Wąwolnica) i stanowi ogromne zagrożenie dla stanu sanitarnego wód. Jednocześnie prawie połowa obszaru tych jednostek leży w granicach parków krajobrazowych. Natomiast w województwach podkarpackim i świętokrzyskim ponad połowa mieszkańców analizowanych gmin jest podłączona do sieci kanalizacyjnej (dla gmin Jarocin i Zarszyn ponad 76\%). Ważnym wskaźnikiem poziomu życia jest udział osób korzystających z sieci gazowej, który dla wybranych gmin nie jest wysoki i zawiera się w przedziale od $25 \%$ do prawie $45 \%$. Są gminy, 
Tabela 1. Wybrane dane i wskaźniki analizowanych jednostek

\begin{tabular}{|c|c|c|c|c|c|c|c|c|c|c|c|c|}
\hline \multirow{3}{*}{\multicolumn{4}{|c|}{ Cechy }} & \multicolumn{9}{|c|}{ Gminy } \\
\hline & & & & 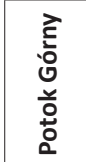 & $\frac{d}{\frac{d}{n}}$ & 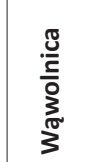 & $\begin{array}{l}\frac{5}{\mathrm{D}} \\
\frac{0}{\frac{0}{2}}\end{array}$ & $\begin{array}{l}3 \\
\frac{3}{2} \\
\frac{2}{0} \\
\text { N }\end{array}$ & $\underset{\substack{\frac{N}{\pi} \\
\text { N }}}{5}$ & 产 & 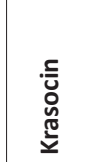 & 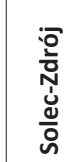 \\
\hline & & & & \multicolumn{3}{|c|}{ woj. lubelskie } & \multicolumn{3}{|c|}{ woj. podkarpackie } & \multicolumn{3}{|c|}{ woj. świętokrzyskie } \\
\hline \multicolumn{4}{|c|}{ Powierzchnia $\left[\mathrm{km}^{2}\right]$} & 111 & 191 & 63 & 91 & 202 & 105 & 132 & 192 & 85 \\
\hline \multicolumn{4}{|c|}{ Gęstość zaludnienia [os./km²] } & 50 & 40 & 77 & 60 & 43 & 88 & 35 & 56 & 60 \\
\hline \multicolumn{4}{|c|}{ Lesistość [\%] } & 27,6 & 55,7 & 14,0 & 41,2 & 64,1 & 23,4 & 46,5 & 43,9 & 10,4 \\
\hline \multicolumn{4}{|l|}{ Wody [\%] } & 0,1 & 0,3 & 0,3 & 0,6 & 1,1 & 1,3 & 0,1 & 0,5 & 0,1 \\
\hline \multicolumn{4}{|c|}{ Grunty rolne* [\%] } & 88,7 & 41,4 & 68,9 & 56,7 & 19,8 & 76,0 & 38,6 & 51,4 & 73,6 \\
\hline \multicolumn{4}{|c|}{ Użytki rolne* [\%] } & 63,0 & 29,9 & 56,7 & 40,8 & 11,9 & 64,5 & 28,6 & 37,0 & 64,3 \\
\hline \multicolumn{4}{|c|}{ Łąki i pastwiska trwałe* [\%] } & 12,7 & 2,5 & 5,9 & 16,8 & 1,3 & 36,9 & 8,6 & 14,3 & 19,7 \\
\hline \multicolumn{4}{|c|}{ Średnia powierzchnia gospodarstwa* [ha] } & 8,2 & 5,3 & 5,0 & 5,0 & 5,0 & 4,8 & 4,6 & 5,8 & 5,8 \\
\hline \multicolumn{4}{|c|}{ Formy ochrony przyrody ${ }^{* *}[\%]$} & - & 48,7 & 46,8 & - & 18,7 & 26,5 & 12,8 & 61,3 & 97,1 \\
\hline \multicolumn{4}{|c|}{ Rezerwaty przyrody [\%] } & - & 0,6 & - & - & 1,9 & - & - & 1,1 & - \\
\hline \multicolumn{4}{|c|}{ Parki krajobrazowe [\%] } & - & 48,2 & 46,8 & - & 18,7 & - & - & 15,3 & 6,1 \\
\hline \multicolumn{4}{|c|}{ Obszary chronionego krajobrazu [\%] } & - & - & - & - & - & 26,5 & 12,4 & 46,0 & 91,0 \\
\hline \multirow{2}{*}{\multicolumn{3}{|c|}{ Natura $2000^{* * *}[\%]$}} & DSO & - & 98,9 & - & 14,6 & 39,0 & 19,9 & - & - & - \\
\hline & & & 500 & - & 21,3 & - & 1,0 & 40,1 & 18,4 & 1,0 & 14,0 & 18,4 \\
\hline \multicolumn{4}{|c|}{ Użytki ekologiczne [\%] } & - & - & - & - & - & - & - & - & 0,1 \\
\hline \multicolumn{4}{|c|}{ Zespoły przyrodniczo-krajobrazowe [\%] } & - & - & 0,6 & - & - & - & - & - & - \\
\hline \multicolumn{4}{|c|}{ Stanowiska dokumentacyjne ${ }^{* * * *}[\%]$} & - & - & - & - & - & - & - & - & - \\
\hline \multicolumn{4}{|c|}{ Pomniki przyrody [szt.] } & 2 & 4 & 11 & 1 & 15 & - & 2 & 7 & 2 \\
\hline \multirow{3}{*}{\multicolumn{2}{|c|}{$\begin{array}{l}\text { Ludność korzysta- } \\
\text { jąca z sieci [\%] }\end{array}$}} & wod & ociągowej & 93,3 & 93,9 & 76,1 & 89,0 & 94,7 & 40,1 & 83,6 & 91,1 & 91,6 \\
\hline & & kana & lizacyjnej & 57,9 & 29,4 & 24,0 & 76,1 & 57,5 & 76,4 & 52,3 & 51,0 & 54,9 \\
\hline & & gazo & wej & 29,1 & 25,4 & 43,6 & 0,1 & 29,3 & 82,4 & - & - & 41,5 \\
\hline \multicolumn{4}{|c|}{$\begin{array}{l}\text { Odpady komunalne ogółem zebrane } \\
\text { na } 1 \text { mieszkańca [kg] }\end{array}$} & 41,1 & 60,5 & 99,5 & 24,4 & 91,4 & 44,9 & 88,0 & 34,8 & 97,7 \\
\hline \multicolumn{4}{|c|}{ Dochód gminy na 1 mieszkańca [zł] } & 3090 & 3259 & 2738 & 2743 & 3058 & 3155 & 4109 & 3266 & 3621 \\
\hline $\begin{array}{l}\text { Dochody wł } \\
\text { gminy [\%] }\end{array}$ & & doch & dach ogółem & 19,9 & 20,2 & 36,2 & 16,8 & 30,6 & 31,9 & 21,1 & 34,0 & 39,8 \\
\hline $\begin{array}{l}\text { Wydatki ma } \\
\text { dżecie gmin }\end{array}$ & MW & e inw & tycyjne w bu- & 10,2 & 30,2 & 5,1 & 19,3 & 17,7 & 20,0 & 36,2 & 21,4 & 3,3 \\
\hline $\begin{array}{l}\text { Wydatki bu } \\
\text { komunalna }\end{array}$ & ug & $\begin{array}{l}\text { miny } \\
\text { nę śr }\end{array}$ & a gospodarkę & 4,9 & 6,3 & 10,5 & 5,5 & 9,4 & 3,3 & 30,1 & 13,9 & 13,3 \\
\hline & ogó & łem & & 226 & 447 & 303 & 278 & 499 & 474 & 196 & 1114 & 294 \\
\hline gospodarki & $w t y$ & & rolniczym & 12 & 36 & 4 & 28 & 25 & 20 & 6 & 31 & 10 \\
\hline narodowej & W s & ekto- & przemysłowym & 12 & 46 & 28 & 42 & 78 & 39 & 32 & 370 & 34 \\
\hline & rze & & budowlanym & 89 & 91 & 47 & 56 & 85 & 62 & 27 & 200 & 55 \\
\hline Udział bezro & tnyc & h zare & jestrowanych [\%] & 4,7 & 9,0 & 7,6 & 11,3 & 10,6 & 9,3 & 8,4 & 10,2 & 5,8 \\
\hline Turystyczne & biekt & y noc & egowe [ob.] & - & 8 & - & - & - & - & 1 & 7 & 9 \\
\hline Długość ście & $\mathrm{k}$ ro & werov & vych [km] & 1,4 & 20,3 & - & - & 9,3 & - & - & 2,6 & 1,7 \\
\hline
\end{tabular}

Źródło: opracowanie własne na podstawie Banku Danych Lokalnych GUS 2014; ${ }^{*}$ dane PSR $2010,{ }^{* *}$ bez Natury 2000, ${ }^{* * *}$ udział powierzchni Natura 2000: OSO (obszar specjalnej ochrony ptaków) wg Dz. U. 25/2011 poz. 133, SOO (specjalny obszar ochrony siedlisk) woj. podkarpackie świętokrzyskie dane RDOŚ, woj. lubelskie na podstawie Geoserwis GDOŚ (pomiary własne), ${ }^{* * *}$ zespół przyrodniczo-krajobrazowy w gminie Wąwolnica jest wykazywany w Centralnym Rejestrze Form Ochrony Przyrody, BDL GUS pomija go. 
które w ogóle nie posiadają stałej sieci gazowej (Fałków, Krasocin). Taka sytuacja źle prognozuje w kontekście konieczności ograniczenia niskiej emisji zanieczyszczeń do atmosfery. Ilość odpadów komunalnych zebranych waha się od prawie $25 \mathrm{~kg}$ do prawie $100 \mathrm{~kg}$ na jednego mieszkańca.

Wybrane wskaźniki ekonomiczne (tab. 1) ilustrują zróżnicowany poziom rozwoju gospodarczego. Najwyższy dochód na jednego mieszkańca mają jednostki województwa świętokrzyskiego i zwykle towarzyszy temu wysoki udział dochodu własnego w dochodach gminy. Najwięcej bezrobotnych zarejestrowanych jest w gminach Jarocin, Zaklików i Krasocin, najmniej - Potok Górny, Solec-Zdrój. Ważnym wskaźnikiem jest również udział wydatków gminy na gospodarkę komunalną i ochronę środowiska, które w 2014 r. najwyższy poziom osiągnęły w gminie Fałków i są skorelowane z wysokimi wydatkami inwestycyjnymi w budżecie jednostki. Zdecydowanie więcej podmiotów gospodarczych zarejestrowano w sektorach budowlanym i przemysłowym niż w rolniczym. W przypadku gminy Krasocin aż 570 i ogółem ich liczna jest najwyższa, przy jednocześnie bardzo wysokim udziale bezrobotnych.

W pracy przeprowadzono ocenę opracowań ekofizjograficznych wykonanych dla obszarów wiejskich wymienionych wyżej gmin południowo-wschodniej Polski. Wytypowano dokumenty, które przygotowane zostały na potrzeby studium i/lub planów miejscowych, ale obejmujące duży obszar jednostki. Tylko takie opracowania teoretycznie powinny dawać realny obraz wpływu uwarunkowań przyrodniczych na kształtowanie struktury funkcjonalno-przestrzennej. Badania szczegółowe obejmowały analizę zawartości i jakości merytorycznej informacji przyrodniczej oraz poprawności ujęcia i formułowania ocen, prognoz i wskazań w tych dokumentach. Kryteria wybrano pod kątem spełnienia wymogów prawnych (Dz. U. 155/2002 poz. 1298) oraz zaleceń przedstawianych w opracowaniach metodycznych i prac, w których dokonano już takiej oceny (Kistowski 2001b, 2002; Pawłat-Zawrzykraj 2008). Kryteria te zestawiono w postaci listy kontrolnej, w której wymieniono kolejne elementy niezbędne w ekofizjografii (tab. 2). Ocenę zawartości i poprawności prowadzono dla każdego z etapów opracowania z użyciem czterostopniowej skali uwzględniającej ilość, treść i wartość merytoryczną: 0 - brak lub znikoma informacja, 1 - informacja niedostateczna (częściowo zła jakość informacji lub jej brak, a do pełnych analiz i oceny konieczne są uzupełnienia), 2 - informacja z niewielkimi brakami (dobra jakość informacji, a niewielkie braki umożliwiają analizy i ocenę) 3 - informacja pełna. Opracowana klasyfikacja ma charakter przybliżony i względny. Należy traktować ją tylko jako określenie następstwa, formę rankingu treści. Ma pomóc w identyfikacji etapów, które są trudne w opracowaniu i wymagają szerszego omówienia. Jest to subiektywna ocena poziomu merytorycznego samego opracowania i znaczenia jego wskazań w planowaniu przestrzennym. Oceny weryfikowano informacjami z literatury dotyczącej środowiska przyrodniczego wybranych obszarów, baz danych geośrodowiskowych i opracowań studialnych oraz w trakcie wizji lokalnej.

\section{Wyniki}

Opracowania ekofizjograficzne zostały wykonane w większości do studium, ale również i/ lub planów miejscowych dla obszaru całych lub wyjątkowo części gmin (jedynie w przypadku Zaklikowa - około 20\% powierzchni) w latach 2003-2012. Pod względem formal- 
nym są generalnie kompletne i poprawnie opracowane. Zachowują układ rozdziałów zgodnie z rozporządzeniem, ale ich treść nie do końca jest zgodna z tytułem i występują braki w zakresie pewnych informacji. Mapy wynikowe załączone do opracowań są przede wszystkim w skali 1:10 000 lub 1:25 000 (Fałków, Krasocin). Wszystkie są opracowaniami podstawowymi.

Po przeprowadzonych analizach stwierdzono następujące prawidłowości (tab. 2):

1. Etap diagnozy - najobszerniejsza i najbardziej szczegółowa część badanych dokumentów. Zawierają one wyczerpującą charakterystykę struktury środowiska, zwykle w układzie komponentowym, ale mają braki w charakterystyce funkcjonowania środowiska. Przedstawiają pełny opis prawnych form ochrony przyrody oraz walorów i zasobów środowiska wraz z określeniem ograniczeń w zagospodarowaniu, ale część z nich nie ujmuje wszystkich obiektów i obszarów wynikających z przepisów szczególnych. W kilku przypadkach nie przedstawiają stanu zagospodarowania i użytkowania środowiska. Natomiast identyfikują źródła antropopresji na miarę dostępnych informacji. W większości dokumentów znajduje się charakterystyka dotychczasowych zmian w środowisku.

2. Etap oceny - rozdział obejmujący ocenę odporności środowiska na degradację i zdolności do regeneracji. Wysuwane wnioski często wymagają lepszych podstaw metodycznych i uzupełnienia szczegółowymi analizami, bo generalnie prowadzone są w formie opisowej. Kilka opracowań ekofizjograficznych nie posiada charakterystyki barier (progów) dla zagospodarowania (te dotyczące wysokich walorów przyrodniczych zwykle podkreślane są przy problematyce ochrony przyrody). Brakuje też prawidłowej oceny przydatności środowiska do realizacji funkcji społeczno-gospodarczych, a wnioski przestawiane są bez uzasadnienia. Dokumenty zawierają rozdział dotyczący oceny zgodności dotychczasowego użytkowania i zagospodarowania z uwarunkowaniami przyrodniczymi, ale uzupełnienia wymaga charakterystyka rzeczywistych konfliktów w środowisku.

3. Etap prognozy - rozdział (o różnej wartości merytorycznej, głównie opis) dotyczący prognozy skutków zmian w środowisku pod wpływem istniejącego zagospodarowania, ale często bez charakterystyki potencjalnych konfliktów.

4. Etap wskazań - charakterystyka w zakresie wskazań do pełnienia różnych funkcji społeczno-gospodarczych i przyrodniczych, ale często występują dysproporcje w kompletności treści dotyczących uzasadnienia wskazań dla funkcji użytkowych i ekologicznych. Pomijane lub marginalizowane są działania odnoszące się do zagadnień minimalizacji zagrożeń występujących w środowisku.

W części ekofizjografii oprócz uwarunkowań przyrodniczych znajduje się charakterystyka społeczno-gospodarcza i opis dziedzictwa kulturowego. Generalnie opracowania zawierają obszerny wykaz źródeł informacji w dołączonej bibliografii (poza jedną ekofizjografią brak cytowań w tekście, jedynie powołania na dokumenty i ekspertyzy). Wyjątkowo znajdują się w nich zapisy co do zakresu wykonanych badań terenowych. Przeprowadzone analizy wskazują w przypadku tych opracowań na praktycznie niewielkie wykorzystanie dostępnej cyfrowej informacji przestrzennej (nawet bezpłatnych form pozyskiwania danych). W ocenie ogólnej tekstu słabo wypada ekofizjografia gminy Jarocin, ale tabela 2 nie uwzględnia szczegółowej inwentaryzacji przyrodniczej (przyroda ożywiona) przygotowanej do dokumentu. Wyjątkowym jest także - w przypadku opracowania dla tej gminy - wykonanie 57 odwiertów badawczych i szczegółowego kartowania terenu, które bardzo 
Tabela 2. Ocena jakości opracowań ekofizjograficznych

\begin{tabular}{|c|c|c|c|c|c|c|c|c|c|}
\hline \multirow{3}{*}{ Kryteria oceny } & \multicolumn{9}{|c|}{ Gminy } \\
\hline & 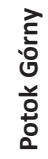 & $\frac{d}{\stackrel{d}{n}}$ & 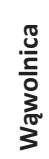 & $\begin{array}{l}\frac{5}{8} \\
\frac{0}{\pi} \\
\frac{0}{2}\end{array}$ & 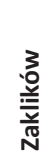 & $\underset{\substack{\text { స్ } \\
\text { N }}}{\text { N }}$ & 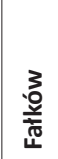 & 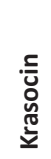 & 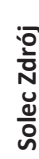 \\
\hline & \multicolumn{3}{|c|}{$\begin{array}{l}\text { woj. } \\
\text { lubelskie }\end{array}$} & \multicolumn{3}{|c|}{$\begin{array}{c}\text { woj. } \\
\text { podkarpackie }\end{array}$} & \multicolumn{3}{|c|}{$\begin{array}{l}\text { woj. święto- } \\
\text { krzyskie }\end{array}$} \\
\hline \multicolumn{10}{|l|}{ Etap diagnozy } \\
\hline Struktura środowiska & 3 & 3 & 3 & 2 & 2 & 3 & 3 & 3 & 3 \\
\hline Funkcjonowanie środowiska & 2 & 1 & 1 & 0 & 0 & 3 & 1 & 0 & 2 \\
\hline Ochrona prawna środowiska & 2 & 3 & 3 & 2 & 3 & 3 & 2 & 3 & 3 \\
\hline Zagospodarowanie i użytkowanie środowiska & 0 & 0 & 2 & 1 & 2 & 1 & 1 & 0 & 1 \\
\hline Źródła antropopresji i ich skutki & 2 & 3 & 2 & 2 & 2 & 2 & 1 & 2 & 3 \\
\hline Dotychczasowe zmiany w środowisku & 3 & 3 & 1 & 2 & 1 & 3 & 3 & 2 & 1 \\
\hline Ocena etapu diagnozy & 12 & 13 & 12 & 9 & 10 & 15 & 11 & 10 & 13 \\
\hline \multicolumn{10}{|l|}{ Etap oceny } \\
\hline $\begin{array}{l}\text { Odporność środowiska na degradację i zdolność } \\
\text { do regeneracji }\end{array}$ & 2 & 3 & 3 & 0 & 2 & 2 & 2 & 2 & 0 \\
\hline Bariery dla zagospodarowania & 0 & 3 & 1 & 1 & 1 & 3 & 0 & 1 & 0 \\
\hline $\begin{array}{l}\text { Potencjał środowiska dla realizacji funkcji } \\
\text { społeczno-gospodarczych }\end{array}$ & 1 & 0 & 1 & 1 & 0 & 1 & 2 & 1 & 1 \\
\hline $\begin{array}{l}\text { Jakość środowiska, zagrożenia i ograniczenia } \\
\text { w zagospodarowaniu }\end{array}$ & 3 & 3 & 3 & 2 & 3 & 3 & 3 & 3 & 2 \\
\hline Stan ochrony walorów i zasobów środowiska & 2 & 3 & 3 & 1 & 3 & 3 & 3 & 3 & 3 \\
\hline $\begin{array}{l}\text { Zgodność dotychczasowego użytkowania i zagospodarowa- } \\
\text { nia z uwarunkowaniami przyrodniczymi }\end{array}$ & 3 & 2 & 1 & 0 & 3 & 3 & 1 & 3 & 0 \\
\hline Konflikty rzeczywiste w środowisku & 2 & 1 & 1 & 0 & 0 & 1 & 1 & 2 & 0 \\
\hline Ocena etapu oceny & 13 & 15 & 13 & 5 & 12 & 16 & 12 & 15 & 6 \\
\hline \multicolumn{10}{|l|}{ Etap prognozy } \\
\hline $\begin{array}{l}\text { Prognozowane zmiany zachodzące w środowisku pod wpły- } \\
\text { wem istniejącego użytkowania i zagospodarowania }\end{array}$ & 1 & 2 & 1 & 1 & 1 & 2 & 2 & 2 & 1 \\
\hline Konflikty potencjalne w środowisku & 1 & 2 & 1 & 0 & 1 & 1 & 1 & 0 & 0 \\
\hline Ocena etapu prognozy & 2 & 4 & 2 & 1 & 2 & 3 & 3 & 2 & 1 \\
\hline \multicolumn{10}{|l|}{ Etap wskazań } \\
\hline Tereny predysponowane do pełnienia funkcji przyrodniczych & 3 & 3 & 3 & 2 & 1 & 3 & 3 & 3 & 3 \\
\hline $\begin{array}{l}\text { Tereny przydatne do pełnienia różnych funkcji } \\
\text { społeczno-gospodarczych }\end{array}$ & 3 & 3 & 3 & 2 & 1 & 2 & 3 & 3 & 3 \\
\hline Możliwości likwidacji i minimalizacji zagrożeń środowiska & 1 & 2 & 1 & 0 & 0 & 1 & 2 & 1 & 1 \\
\hline Ocena etapu wskazań & 7 & 8 & 7 & 4 & 2 & 6 & 8 & 7 & 7 \\
\hline Badania terenowe & 0 & 0 & 2 & 3 & 1 & 0 & 0 & 1 & 2 \\
\hline Źródła informacji przyrodniczej & 2 & 2 & 3 & 1 & 1 & 2 & 2 & 2 & 2 \\
\hline Część kartograficzna & 2 & 3 & 3 & 3 & 2 & 3 & 3 & 3 & 3 \\
\hline Ocena końcowa & 38 & 45 & 42 & 26 & 30 & 45 & 39 & 40 & 34 \\
\hline
\end{tabular}

Źródło: opracowanie własne, kryteria oceny wyodrębniono na podstawie: Rozporzqdzenie... (2002), M.

Kistowski (2001b, 2002), A. Pawłat-Zawrzykraj (2008). Ocena: 0 - brak lub znikoma informacja, 1 - informacja niedostateczna, 2 - informacja z niewielkimi brakami, 3 - informacja pełna. 
wzbogacają treść map w skali 1:10 000 (rzeźby terenu, warunków gruntowo-wodnych i ekofizjograficznych), stanowiących doskonałą podstawę dla dalszych prac planistycznych.

Jakość opracowań ekofizjograficznych nie jest przedmiotem zbyt dużej liczby badań. A. Pawłat-Zawrzykraj (2008) wskazuje na zróżnicowany ich poziom i braki: pomijanie oceny krajobrazu i zgodności dotychczasowego użytkowania i zagospodarowania oraz etapu oceny. M. Jakiel (2015) podkreśla, że niska wartość merytoryczna ekofizjografii skutkuje brakiem realnego znaczenia w procesie planistycznym. Natomiast P. Fogel i J. Kuskowski (2015) przedstawiają ocenę załączników graficznych w części dotyczącej rozpoznania i diagnozy stanu środowiska, w której również dostrzegają problemy z charakterystyką krajobrazu. Przeważają opracowania ekofizjograficzne, które pozornie spełniają wymogi formalne, ale istnieje grupa reprezentująca wysoki poziom merytoryczny. Wniosek końcowy badań nie jest optymistyczny: „wyniki analizy dostępnych dokumentów (...) wskazują, że większość z nich - poza formalnym charakterem - nie będzie odgrywała istotnej roli w podejmowaniu decyzji o sposobie gospodarowania" (Fogel i Kuskowski 2015, s. 58).

\section{Podsumowanie}

Obszary wiejskie mają złożone problemy społeczno-gospodarcze, funkcjonalne i przestrzenne, których źródeł upatruje się przede wszystkim w słabszym poziomie rozwoju. Samorządy próbują inicjować lub wzmocnić istniejące już kierunki rozwoju lokalnego poprzez planowanie strategiczne i przestrzenne, w którym wskazują na znaczącą rolę zasobów przyrodniczych. W wielu przypadkach znaczenie tych zasobów jest przeceniane lub w obecnych warunkach nie mogą być one włączone do procesów gospodarczych. Często sama możliwość ich eksploatacji czy wykorzystania staje się źródłem konfliktu. Problemy te powinny znaleźć swoje kompleksowe rozwiązania w ekofizjografii. Należy zastanowić się, czy nie wskazać dalszych zastosowań tego dokumentu, jak to już kilkanaście lat temu postulował R. Kowalczyk (2001), w planowaniu i programowaniu rozwoju gospodarczego oraz rozszerzyć obszary jego wykorzystania w jednostkach samorządu terytorialnego, np. w aspekcie wdrażania polityki ekologicznej.

Przeprowadzona ocena opracowań ekofizjograficznych potwierdza wnioski z innych prac. Generalnie spełniają one warunki formalne, ale wielu przypadkach nie są źródłem wystarczającej informacji o uwarunkowaniach przyrodniczych dla planowania lokalnego. Zawierają pełną charakterystykę komponentów środowiska przyrodniczego (poza nielicznymi wyjątkami). Stwierdzono jednak elementy, które wymagają korekt i uzupełnień. Występują braki w zakresie identyfikacji: a) problemów zagospodarowania i użytkowania środowiska, b) oceny odporności środowiska na degradację, c) barier dla zagospodarowania, d) rzeczywistych i potencjalnych konfliktów. Mimo ogromnego zwiększenia zawartości baz cyfrowej informacji przestrzennej dotyczących zasobów przyrody, ochrony i stanu środowiska, przeprowadzone analizy tych wybranych dokumentów wskazują na brak ich bezpośredniego wykorzystania w ekofizjografii. Nadal należy pracować nad metodyką rozwiązywania pewnych problemów wskazanych do oceny w opracowaniach.

Osobną kwestię stanowią opracowania ekofizjograficzne sporządzane do planów miejscowych obejmujących niewielkie obszary, które rozważają zupełnie inną skalę i charakter problemów, np. dla terenu planowanej jednorodzinnej zabudowy mieszkaniowej. Pewnym mankamentem jest fakt, iż brak jest konkretnych wskazań co do kształtu dokumen- 
tów problemowych. Zapisy Rozporzq̨dzenia (2002) są zbyt ogólne. Szczególnie dotyczy to określenia katalogu, dla jakich grup inwestycji powinny być realizowane. W części przypadków wykonywane są opracowania podstawowe, a projekt zmiany studium czy planu miejscowego przygotowywany jest pod funkcję „kolizyjną" z ochroną środowiska przyrodniczego i krajobrazu lub istniejącym użytkowaniem, np. na potrzeby uruchomienia eksploatacji surowców mineralnych czy lokalizacji elektrowni wiatrowych.

\section{Literatura}

Bański J., 2013, O przyszłości polskiej wsi, Studia Obszarów Wiejskich, 31, s. 9-24.

Bański J., Pantylej W., Janicki W., Flaga M., Wesołowska M., 2014, Współczesne przekształcenia społeczno-gospodarcze a potencjał ludnościowy wschodniej Polski, Studia Obszarów Wiejskich, 36.

Bar M., 2011, Wprowadzenie do Działu VII. Ochrona środowiska w zagospodarowaniu przestrzennym i realizacji inwestycji, [w:] M. Górski, M. Pchałek, W. Radecki, J. Jerzmański, M. Bar, S. Urban, J. Jendrośka (red.), Prawo ochrony środowiska. Komentarz, Wyd. C. H. Beck, Warszawa, s. 250-275.

Bar M., Górski M., Jendrośka J., Jerzmański J. Pchałek M., Radecki W., 2011, Tytuł I. Przepisy ogólne. Dział II. Definicje i zasady ogólne, [w:] M. Górski, M. Pchałek, W. Radecki, J. Jerzmański, M. Bar, S. Urban, J. Jendrośka (red.), Prawo ochrony środowiska. Komentarz, Wyd. C. H. Beck, Warszawa, s. 21-129.

Bródka S. (red.), 2010, Praktyczne aspekty ocen środowiska przyrodniczego, Bogucki Wydawnictwo Naukowe, Poznań.

Cichocki Z., 2006, Problematyka opracowań ekofizjograficznych do projektów miejscowych planów zagospodarowania przestrzennego, Instytut Ochrony Środowiska, Warszawa.

Czarnecki A., 2009: Rola urbanizacji w wielofunkcyjnym rozwoju obszarów Wiejskich, IRWiR PAN, Warszawa.

Derucka I., 2010, Rola opracowań ekofizjograficznych w praktyce planistycznej, Administracja: teoria, dydaktyka, praktyka, 1 (18), s. 112-128.

Derucka I., 2013, Prawne gwarancje realizacji zadań ochrony środowiska w procedurze planowania przestrzennego w gminie, Uniwersytet Wrocławski, Wrocław.

Dubel K., 2000, Uwarunkowania przyrodnicze w planowaniu przestrzennym, Wydawnictwo Ekonomia i Środowisko, Białystok.

Ekofizjografia gminy Solec Zdrój, 2003, Świętokrzyskie Biuro Rozwoju Regionalnego, Kielce.

Ekofizjografia gminy Susiec (opracowanie podstawowe), 2011, Wójt Gminy Susiec. Susiec.

Ekofizjografia (opracowanie podstawowe), 2003, Urząd Gminy Potok Górny, Tomaszów Lubelski.

Ekofizjografia podstawowa gminy Wąwolnica, 2005, Wójt Gminy Wąwolnica, Wąwolnica.

Feltynowski M., 2009, Polityka przestrzenna obszarów wiejskich. W kierunku wielofunkcyjnego Rozwoju, Wydawnictwo CeDeWu, Warszawa.

Fogel A. (red.), 2014, Ograniczenia w zabudowie i zagospodarowaniu terenu a ład przestrzenny. Przepisy odrębne wobec ustawy o planowaniu i zagospodarowaniu przestrzennym, IGPiM, Warszawa.

Fogel P., Kuskowski J., 2015, Ocena treści wybranych opracowań ekofizjograficznych w zakresie rozpoznania i diagnozy stanu, powstajacych na potrzeby kształtowania polityki przestrzennej gmin w Polsce, Człowiek i środowisko, 39, 1, s. 43-59. 
Gruszecki K., 2011, Prawo ochrony środowiska. Komentarz, Lex a Wolters Kluwer business, Warszawa.

Haładyj A., Trzewik J., 2014, Pojęcie strategicznych zasobów naturalnych - uwagi krytyczne, Przegląd Prawa Ochrony Środowiska, 1, s. 27-46.

Heffner K., 2015, Przestrzeń jako uwarunkowanie rozwoju obszarów wiejskich w Polsce, Wieś i Rolnictwo, 2 (167), s. 83-103.

Jakiel M., 2015, Rola i jakość opracowań przyrodniczych w procedurze planistycznej na wybranym przykładzie z otuliny Słowińskiego Parku Krajobrazowego, Problemy Ekologii Krajobrazu, 39, s. 95-102.

Karpa A., Łaguna T., Witkowska-Dąbrowska M., Zapotoczna M., 2010, Środowisko i zasoby naturalne, [w:] T. Łaguna, M. Witkowska-Dąbrowska (red.), Zarządzanie zasobami środowiska, Wydawnictwo Ekonomia i Środowisko, Białystok-Olsztyn, s. 11-47.

Kistowski M., 2001a, Wybrane problemy metodologiczne i terminologiczne opracowań ekofizjograficznych, Problemy Ocen Środowiskowych, 3 (14), s. 32-39.

Kistowski M., 2001b, Zarys koncepcji opracowań ekofizjograficznych, cz. I, Problemy Ocen Środowiskowych, 4 (15), s. 57-66.

Kistowski M., 2002, Zarys koncepcji opracowań ekofizjograficznych, cz. II, Problemy Ocen Środowiskowych, 1 (16), s. 52-59.

Kistowski M., 2003, Struktury i przepływy informacji dla potrzeb planowania przestrzennego, Człowiek i Środowisko, 27, 1-2, s. 83-96.

Kistowski M., 2009, Zasoby środowiska, [w:] J. Ciechanowicz-McLean (red.), Leksykon ochrony środowiska, Wyd. C.H. Beck, Warszawa, s. 406-414.

Kistowski M., 2014, Źródła danych, [w:] J. Solon (kierownik projektu), Identyfikacja i ocena krajobrazów - metodyka oraz główne założenia, IGiPZ PAN, Warszawa (www.igipz.pan.pl), s. 10-21.

Kistowski M., Pchałek M., 2009, Natura 2000 w planowaniu przestrzennym - rola korytarzy ekologicznych. Ministerstwo Środowiska, Warszawa.

Kowalczyk R., 2001, Opracowanie ekofizjograficzne - przyrodniczy fundament wdrażania zasad zrównoważonego rozwoju w planach zagospodarowania przestrzennego, Problemy Ocen Środowiskowych, 1 (12), s. 25-31.

Kozłowski S., 1996, Przyrodnicze kryteria gospodarki przestrzennej, Wydawnictwo KUL, Lublin.

Macias A., Bródka S., 2014, Przyrodnicze podstawy gospodarowania przestrzeniq, Wydawnictwo Naukowe PWN, Warszawa.

Nowak M.J. 2013, Planowanie i zagospodarowanie przestrzenne. Przepisy szczególne, Komentarz, Wydawnictwo CeDeWu, Warszawa.

Opracowanie ekofizjograficzne do zmiany studium uwarunkowań i kierunków zagospodarowania przestrzennego gminy Fałków, 2005, Fałków.

Opracowanie ekofizjograficzne gminy Krasocin, 2008, Urząd Gminy w Krasocinie, Łódź.

Opracowanie ekofizjograficzne na potrzeby I zmiany studium uwarunkowań i kierunków zagospodarowania przestrzennego gminy Zaklików, 2012, Urząd Gminy Zaklików, Zaklików.

Opracowanie ekofizjograficzne podstawowe dla potrzeb studium uwarunkowań i kierunków zagospodarowania przestrzennego i miejscowych planów zagospodarowania przestrzennego gminy Jarocin, 2010, Gmina Jarocin, Rzeszów.

Opracowanie ekofizjograficzne podstawowe dla terenu gminy Zarszyn dla potrzeb miejscowych planów zagospodarowania przestrzennego, 2006, Gmina Zarszyn, Zarszyn.

Papińska E., 2007, Rola opracowań ekofizjograficznych w procesie planowania przestrzennego, Czasopismo Techniczne, 7A, s. 185-190. 
Pawłat-Zawrzykraj A., 2008, Ocena wybranych opracowań ekofizjograficznych, Przegląd Naukowy Inżynieria i Kształtowanie Środowiska, 3 (41), s. 69-77.

Poskrobko B., 2007, Teoretyczne podstawy budowy systemu zarzq̨dzania środowiskiem, [w:] B. Poskrobko (red.), Zarzqdzanie środowiskiem, PWE, Warszawa, s. 9-76.

Rakoczy B., 2013, Tytuł I. Przepisy ogólne, [w:] Z. Bukowski, E.K. Czech, K. Karpus, B. Rakoczy, Prawo ochrony środowiska. Komentarz, Wydawnictwo LexisNexis, Warszawa, s. 37-64.

Rakoczy B., 2014, Pojęcie gospodarowania zasobami środowiska, [w:] B. Rakoczy, M. Szablewska, K. Karpus (red.), Prawne aspekty gospodarowania zasobami środowiska. Korzystanie z zasobów środowiska, TNOik Dom Organizatora, Toruń, s. 19-30.

Rosner A. Stanny M., 2014, Monitoring rozwoju obszarów wiejskich. Etap I. Przestrzenne zróżnicowanie poziomu rozwoju społeczno-gospodarczego obszarów wiejskich w 2010 roku, Fundacja EFRWP, IRWiR PAN, Warszawa.

Rozporzqdzenie Ministra Środowiska z dnia 9 września 2002 r. w sprawie opracowań ekofizjograficznych. Dziennik Ustaw 155/2002, poz. 1298.

Rozporządzenie Ministra Środowiska z dnia 12 stycznia 2011 r. w sprawie obszarów specjalnej ochrony ptaków. Dziennik Ustaw 25/2011, poz. 133.

Różycka W., 1986, Zakres badań ekofizjograficznych i zasady wdrażania wyników do planów zagospodarowania przestrzennego, Człowiek i Środowisko, 10, 4, s. 515-531.

Stala Z., 1990, Ekofizjograficzne zasady kształtowania struktury przestrzennej miast w planach zagospodarowania przestrzennego, IGPiK, Warszawa.

Stala Z. 2001, Opracowania ekofizjograficzne, Człowiek i Środowisko, 25 (2), s. 217-229.

Szlachetko J.H., 2014, Wpływ braku opracowania ekofizjograficznego na proces planistyczny, Samorząd Terytorialny, 10, s. 16-20.

Szulczewska B., Cieszewska A., Giedych R. (red.), 2009, Opracowanie ekofizjograficzne wykonane na potrzeby Studium uwarunkowań i kierunków zagospodarowania przestrzennego miasta Kielce, SGGW Katedra Architektury Krajobrazu, Warszawa.

Ustawa Prawo ochrony środowiska z dnia 27 kwietnia 2001 r., Dziennik Ustaw 62/2001, poz. 627, (tekst jednolity Dz. U. tekst jednolity Dz. U. z dnia 16 kwietnia 2016 r., poz. 672.).

Ustawa. o zachowaniu narodowego charakteru strategicznych zasobów naturalnych kraju z dnia 6 lipca 2001 r., Dziennik Ustaw 2001/97 poz. 1057 z późn. zm.

Ustawa o planowaniu i zagospodarowaniu przestrzennym z dnia 27 marca 2003 r., Dziennik Ustaw 80/2003, poz. 717, (tekst jednolity Dz. U. z dnia 13 maja 2016 r., poz. 778).

Ustawa o ochronie przyrody z dnia 16 kwietnia 2004 r., Dziennik Ustaw 92/2004 poz. 880, (tekst jednolity Dz. U. z dnia 21 września 2015 r. poz. 1651)

Wilkin J. (red.), 2010, Wielofunkcyjność rolnictwa. Kierunki badań, podstawy metodologiczne i implikacje praktyczne, IRWiR PAN, Warszawa.

\section{Summary}

An eco-physiographic study is a basic study describing the natural environment conditions for spatial planning purposes. Based on a comprehensive examination of the natural environment, the study indicates areas predisposed to performing specific socio-economic and ecological functions. The study provides information indispensable for the preparation of the draft provincial spatial development plan, spatial development conditions and directions study and local master plan. The objective of this article is to evaluate eco- 
physiographic studies prepared for nine rural districts in south-eastern Poland. Detailed research focused on the analysis of the content and quality of environmental data as well as the correct presentation and formulation of assessments, forecasts and recommendations in these documents. From the formal perspective, these eco-physiographic studies are complete and consistent with the legal requirements. They contain a full description of the natural environment components. It was found, however, that some amendments and additions are required with regard to the insufficient identification of a) challenges to the development and use of the environment, b) assessment of the resistance of the environment to degradation, c) obstacles to development, and d) actual and potential conflicts. 


\section{Informacja dla Autorów}

Studia Obszarów Wiejskich to wydawnictwo publikujące oryginalne opracowania naukowe z zakresu geografii społeczno-ekonomicznej, geografii wsi i przestrzennego zagospodarowania kraju w języku polskim lub/i angielskim. Zapraszamy Autorów do nadsyłania wartościowych artykułów. Przestrzeganie poniższych zaleceń formalnych usprawni prace redakcyjne i przyczyni się do szybszej publikacji nadsyłanych materiałów.

Uwagi ogólne. Zgłoszenie przez autora (ów) tekstu do Studiów Obszarów Wiejskich oznacza, że nie jest on przewidziany do druku w innym wydawnictwie. Jest także jednoznaczne z wyrażeniem zgody na jego rozpowszechnianie przez IGiPZ PAN w formie drukowanej i elektronicznej z wykorzystaniem licencji Creative Commons: uznanie autorstwa, 3.0 Polska.

Podstawowym sposobem przekazania materiałów do druku jest przesłanie tekstu i załączników na płycie CD na adres wskazany przez redakcję. Tekst artykułu powinien być napisany zwięźle, ale jasno, przy użyciu edytora MS WORD. Objętość artykułu nie powinna przekraczać 6000 słów. Wszystkie załączniki graficzne muszą być dostarczone w formie osobnych plików. Preferowany format dla danych liczbowych to MS EXCEL, a dla załączników graficznych pliki w formacie JPG, TIF, EPS, CDR*, AL* (*Wymagany zapis do edycji w starszych wersjach programów, na chwilę obecną: Corel Draw do wersji 14, Adobe llustrator do wersji 11).

Strona tytułowa. Na pierwszej stronie należy w kolejności umieścić: tytuł pracy w języku polskim, tytuł pracy w języku angielskim, imię i nazwisko autora/autorów (cyfry arabskie po nazwisku, umieszczane jako indeks górny, określają odp. afiliację), afiliację, adres (y), e-mail (e), zarys treści (maksymalnie 200 słów powinien zawierać: sformułowanie celu pracy/badań, identyfikację obiektu badań, przedmiotu rozważań, istotę stosowanej metody, najważniejsze wyniki i wnioski), słowa kluczowe (podaje się nie więcej niż 5 słów kluczowych).

Tekst artykułu pisany czcionką Calibri Light 10, interlinia 1,0. Nie należy nadawać odrębnych stylów znakowych i akapitowych oraz specyficznych wyróżnień (kolor, podkreślenia, itd.) fragmentom tekstu. W tekście opracowania, przy powoływaniu się na literaturę, należy podawać nazwisko autora oraz rok publikacji, np. (Nowak 2004; Kowalski 2005, 2007) lub według A. Nowaka (2006), a przy cytowaniu również numer strony, np. według A. Nowaka (2006, s. 6). W powołaniach na więcej prac tego samego autora, które ukazały się w tym samym roku, podaje się: (Nowak 1987a, b). W przypadku wspólnej publikacji dwóch autorów podaje się: (Kowalski i Nowak 1999), a trzech i więcej autorów: (Kowalski i in. 2006).

Podziękowania - opcjonalnie oraz ewentualna informacja o źródłach finansowania publikacji i wkładzie innych podmiotów w opracowanie publikacji (zgodnie z wymogami jakościowymi i standardami etycznymi opisanymi niżej) należy zamieścić po zasadniczym tekście.

Rysunki i fotografie z podpisami i objaśnieniami w j. polskim i angielskim powinny być zamieszczone w tekście, a ponadto dołączone w postaci osobnych plików posiadających numerację zastosowaną w tekście. Wymagana jest wysoka rozdzielczość rysunków i fotografii (min. 300 dpi w plikach rastrowych JPG lub TIF). Dopuszczalne formaty wektorowe (EPS, Al*, CDR*). Tytuł ryciny i źródło w języku polskim i angielskim powinny znajdować się poza rysunkiem, w pliku tekstowym. Objaśnienia znaków legendy w języku polskim i angielskim można zamieścić w obrębie ryciny lub poza nią. Rysunki i fotografie drukowane są w kolorze czarno-białym. Należy upewnić się, że po zastąpieniu ew. kolorów skalą szarości i przeskalowaniu do rozmiarów maksymalnie 12,5 x $20 \mathrm{~cm}$ będą one wystarczająco czytelne. Zalecany krój czcionki dla napisów będących częścią grafiki (bez możliwości edycji) to Calibri.

Tabele powinny być zamieszczone w tekście. Każda tabela powinna zawierać zwięzły tytuł (u góry) w języku polskim, kolejny numer i źródło danych (u dołu). Wszystkie skróty powinny być objaśnione (tytuł, źródło i objaśnienia należy dołączyć jedynie w pliku tekstowym). W komórkach tabeli nie powinny znajdować się znaki tabulacji (Tab) ani końca akapitu (Enter) - w razie potrzeby można korzystać ze znaku wymuszonego końca wiersza (Shift+Enter). Należy unikać nietypowego formatowania (jak wypełnienia kolorystyczne komórek, różne grubości linii, itd.).

Spis literatury ograniczony do literatury cytowanej, w porządku alfabetycznym, należy zamieścić poniżej tekstu artykułu według poniższego wzoru:

Artykuły w czasopismach i seriach wydawniczych:

Wójcik M., 2011, Współczesne kierunki i podejścia badawcze w geografii wsi, Przegląd Geograficzny, 83, 2, s. $163-185$.

Kulikowski R., 2013, Obszary wiejskie województwa podlaskiego w perspektywie 2050 roku, Studia Obszarów Wiejskich, 31, s. 129-142.

Rozdziały w pracach zbiorowych:

Zegar J.S., 2014, Typy społeczno-ekonomiczne indywidualnych gospodarstw rolnych według rodzaju gmin, [w:] R. Rudnicki. M. Kluba (red.), Zintegrowany rozwój obszarów wiejskich w świetle polityki Unii Europejskiej, t. 1, Rolnictwo i Wspólna Polityka Rolna, Wydawnictwo Naukowe Uniwersytetu Mikołaja Kopernika, Toruń, s. $57-73$.

Książki

Bański J., 2006, Geografia polskiej wsi, PWE, Warszawa. 
Streszczenie. Na końcu opracowania powinno być zamieszczone streszczenie w języku angielskim zweryfikowane przez native-speakera. Objętość streszczenia: około 250-400 słów.

Ocena artykułów i dopuszczenie ich do druku. Wszystkie artykuły niespełniające powyższych zasad będą odsyłane do poprawy. Artykuły podlegają ocenie przez dwóch recenzentów. W procesie recenzowania stosowane jest rozwiązanie, w którym autor (zy) i recenzenci nie znają swoich tożsamości (tzw. „double-blind review proces").Wynik recenzji będzie miał decydujący wpływ na możliwość opublikowania materiału w Studiach Obszarów Wiejskich.

Zasady dotyczące recenzowania w Studiach Obszarów Wiejskich

1. Do oceny każdej publikacji powołuje się co najmniej dwóch niezależnych recenzentów spoza jednostki, w której afiliowani są autorzy publikacji.

2. W przypadku tekstów powstałych w języku obcym, co najmniej jeden z recenzentów jest afiliowany w instytucji zagranicznej innej niż narodowość autora pracy.

3. W procesie recenzowania stosowane jest rozwiązanie, w którym Autor(zy) i recenzenci nie znają swoich tożsamości (tzw. double-blind review proces).

4. Wyznaczając recenzentów redakcja wydawnictwa zachowuje ponadto zasadę zapobiegania konfliktom interesów między recenzentem a autorem.

5. Recenzje mają formę pisemną i kończą się jednoznacznym wnioskiem do dopuszczenia artykułu do publikacji lub jego odrzucenia, względnie warunkowego dopuszczenia tekstu do publikacji po jego poprawieniu przez autora według uwag zawartych w recenzji. W takiej sytuacji recenzent może zastrzec sobie prawo do ponownego zrecenzowania pracy, po dokonaniu przez autora poprawek wskazanych w pierwszej recenzji. Do publikacji dopuszczane będą prace posiadające dwie pozytywne recenzje (zawierające wniosek o dopuszczenie do publikacji) - wzór recenzji poniżej.

6. Zasady kwalifikowania lub odrzucenia publikacji oraz formularz recenzji są podane do publicznej wiadomości na stronie internetowej wydawnictwa.

7. Nazwiska recenzentów nie są publikowane przy poszczególnych artykułach

Studia Obszarów Wiejskich

ARKUSZ RECENZII

Tytuł recenzowanego artykułu ......

1. Czy zagadnienie przedstawione w artykule jest istotne pod względem naukowym i może zainteresować szersze grono czytelników? Czy praca przedstawia oryginalne materiały autorskie, stanowi syntezę czy przegląd badań?

2. Czy tematyka artykułu odpowiada tematyce tomu i profilowi Studiów Obszarów Wiejskich?

3. Czy sposób przedstawienia tematu jest prawidłowy, to znaczy (odpowiedź: Tak lub Nie)

- czy tytuł dokładnie odpowiada treści?

- czy zagadnienie zostało przedstawione w sposób logiczny?

- czy wnioski wynikają z treści pracy?

- czy odpowiednie pozycje literatury zostały uwzględnione?

- czy ilustracje (tabele wykresy, mapy) są czytelne i wystarczające

4. Sugerowane poprawki (rozwinięcie na odwrotnej lub osobnej stronie). Drobne poprawki mogą być zaznaczone w tekście artykułu.

\section{WNIOSEK:}

Ocena artykułu:

Bardzo dobra

$\square$ Dobra

$\square$ Przeciętna

口 Temat interesujący, ale słabo przedstawiony

Artykuł warto opublikować (właściwe podkreślić):

- w wersji przedstawionej przez autora (-ów)

- z ewentualnymi drobnymi poprawkami sugerowanymi przez recenzentów i/lub redakcję

- po dokonaniu zasadniczych zmian sugerowanych przez recenzentów i redakcję

- artykuł nie nadaje się do publikacji

Wymogi jakościowe i standardy etyczne. W trosce o dochowanie najwyższych standardów redakcyjnych oraz w celu zapobieżenia nierzetelności w publikacjach naukowych określanych jako tzw. ghostwriting i guest authorship Redakcja Studiów Obszarów Wiejskich wymaga od autorów ujawniania informacji o podmiotach przyczyniających się do powstania publikacji (wkład merytoryczny, rzeczowy, finansowy etc.). W tym celu zobowiązuje się autorów do zachowania następujących standardów podczas przygotowywania tekstów składanych do publikacji: 1) w przypadku publikacji naukowych, które nie zostały wykonane samodzielnie, tzn. opracowano je we współautorstwie lub z wykorzystaniem pomocy wyspecjalizowanego podmiotu (osoby fizycznej lub praw- 
nej), w końcowej części pracy (w punkcie: „Podziękowania”) należy zawrzeć notę, w której ujawniany jest wkład poszczególnych autorów (współautorów) w powstanie publikacji (artykułu, monografii). Oznacza to konieczność podania ich afiliacji oraz kontrybucji, tj. informacji kto jest autorem koncepcji, założeń, zastosowanych metod, protokołu itp., wykorzystywanych w toku pracy badawczej - przygotowywania publikacji; główną odpowiedzialność ponosi autor zgłaszający manuskrypt. 2) Autor/współautorzy podają ponadto informację o ewentualnych źródłach finansowania publikacji, wkładzie instytucji naukowo-badawczych, stowarzyszeń i innych podmiotów w opracowanie publikacji (financial disclosure). Redakcja wydawnictwa informuje, że wszelkie przejawy nierzetelności naukowej, zwłaszcza łamania i naruszania zasad etyki obowiązujących w nauce, w tym wykryte przypadki ghostwriting, guestauthorship będą dokumentowane i oficjalnie demaskowane, włącznie z powiadomieniem odpowiednich podmiotów (instytucje zatrudniające autorów, towarzystwa naukowe, stowarzyszenia edytorów naukowych itp.).

Z ghostwriting mamy do czynienia wówczas, gdy ktoś wniósł istotny wkład w powstanie publikacji, bez ujawniania swojego udziału jako jeden z autorów lub bez wymieniania jego roli w Podziękowaniach zamieszczonych w publikacji.

Z guest authorship (honorary autorship) mamy do czynienia wówczas, gdy udział autora jest znikomy lub w ogóle nie miał miejsca, a pomimo to jest autorem/wspłautorem publikacji.

Wersja pierwotna. Wersja papierowa i elektroniczna są tożsame, jednakże Redakcja wskazuje wersję papierową jako wersję pierwotną czasopisma.

\section{Adres Redakcji}

ul. Twarda 51/55, 00-818 Warszawa

tel. (+48 22) 69788 34, fax (+48 22) 6206221

e-mail: b.solon@twarda.pan.pl

Redaktor Naczelny Studiów Obszarów Wiejskich 